\title{
Magnetic properties of hexamethylbenzene
}

\author{
Fei Yen \\ School of Sciences, Harbin Institute of Technology Shenzhen Graduate School \\ University Town, Shenzhen 518055, P. R. China \\ E-mail: fyen@hit.edu.cn
}

Received October 24, 2018

\begin{abstract}
Magnetic susceptibility $\chi(T)$ measurements on hexamethylbenzene $\mathrm{C}_{6}\left(\mathrm{CH}_{3}\right)_{6}(\mathrm{HMB})$ as well as its deuterated analogue $\mathrm{C}_{6}\left(\mathrm{CD}_{3}\right)_{6}\left(\mathrm{HMB}-d_{18}\right)$ in the range of $2-300 \mathrm{~K}$ are presented. When cooling, an uptick is detected in $\chi(T)$ when the external magnetic field is applied along the direction of the molecular planes which coincide with the onset of intra-molecular coupling of the $\mathrm{CH}_{3}$ groups at $T_{\mathrm{C} \mathrm{H}}^{\prime}=110.8 \mathrm{~K}$ for $\mathrm{HMB}$ and $\mathrm{CD}_{3}$ groups at $T_{\mathrm{C} D}^{\prime}=126.7 \mathrm{~K}$ for HMB- $d_{18}$. Upon warming, the same discontinuities occur near $T_{\mathrm{C} H}=117.8 \mathrm{~K}$ and $T_{\mathrm{C} D}=132.2 \mathrm{~K}$. Near $40 \mathrm{~K}$, a peak anomaly is observed believed to be the system accessing its ground tunneling state. Near $20 \mathrm{~K}$, the divergence of $\chi(T)$ suggests the establishment of long-range ordering, viz., inter-molecular gearing of the methyl group rotations. When the external magnetic field is applied perpendicular to the molecular planes, $\chi(T)$ is independent of temperature. Our findings reveal how correlated periodic motion of protons, a phenomenon inherent in many molecular solids, exhibits magnetic behavior that has been thus far overlooked.
\end{abstract}

Keywords: magnetic susceptibility, molecular interaction, phase transition, methyl groups.

The cohesive forces binding hexamethylbenzene $\mathrm{C}_{6}\left(\mathrm{CH}_{3}\right)_{6}(\mathrm{HMB})$ molecules to form into its triclinic crystal structure [1,2] are mainly van der Waals [3] which are rather weak in contrast to metallic, ionic and covalent compounds. As such, entire molecules are capable of rotating about their $C_{6}$ axes at room temperature [4,5]. Near $160 \mathrm{~K}$, the periodic potentials within the lattice rise to the level of inhibiting $C_{6}$ rotations, however, the individual methyl groups $\left(\mathrm{CH}_{3}\right)$ remain capable of rotating freely about their $C_{3}$ axes [6]. Near $118 \mathrm{~K}$, the system phase transitions into a near-cubic phase [7]. At this same temperature, the methyl groups become ordered, or "geared", meaning that as one methyl group rotates about its clockwise direction, its adjacent methyl groups rotate anti-clockwise [8-13]. As the temperature is further lowered, the gearing intensifies [10]. At temperatures below $\sim 40 \mathrm{~K}$, numerous reports have suggested that the methyl groups exhibit periodic rotational tunneling [6,7,14-19].

The rotational motion of a methyl group at low temperatures mainly involves a concerted tunneling of three protons since the carbon atom lies on the axis of rotation. Moreover, the electrons also reside near the carbon atom rendering the outer extremity to be comprised of only positive charges. The diamagnetism in nearly all compounds stems from individual electrons of mass $m_{e}$ orbiting at a radius $r_{e}$ at a frequency $f$ commensurate to the strength of the applied magnetic field $H$, is trivially expressed as [20]

$$
\mu_{e}=-\frac{e^{2} H}{4 m_{e}} r_{e}^{2},
$$

where $e$ is the elemental unit of charge. In the case of HMB, despite that the mass of the proton $m_{p}$ is $\sim 1836$ times larger than $m_{e}$, the area the three protons in each methyl group traces in one revolution is in the Angstrom squared vicinity, near $10^{10}$ times larger than that of an electron. One key difference however, is that the protons are confined to only being capable of rotating about a fixed plane (determined by the three proton sites within each methyl group) in accords to confinements set forth by the periodic potential barriers. Hence, the magnetic moment generated by the protons of each methyl group also depends on the $\theta$ and $\phi$ angles at which $H$ is in respect with the planes of rotation and may be expressed as

$$
\mu_{p}=\frac{N_{p} e^{2} H}{4 m_{p}} r_{p}^{2} \cos \theta \cos \phi,
$$

where $N_{p}=3$ represents the three protons of the methyl group. For simplicity, the three protons are treated to rotate about a circle with radius $r_{p}$, whereas in actuality they trace out a near equilateral triangle. We note that Eq. (2) does not take into account the inherent spin of the protons, since similar to diamagnetism, contributions from the proton magnetic moments end up cancelling each other out due to 
the even number of methyl groups. Nevertheless, the contribution of Eq. (2) to the overall magnetic susceptibility, especially when thermal fluctuations become low enough to hinder the coupling between adjacent methyl groups such as when gearing sets in, should be appreciable and detectable by modern-day instrumentation. For these reasons, the temperature-dependent magnetic susceptibility of HMB [21] and its deuterated analogue $\mathrm{C}_{6}\left(\mathrm{CD}_{3}\right)_{6}, \mathrm{HMB}-d_{18}$ [22], were measured in the range of $2-300 \mathrm{~K}$ to explore the possible existence of magnetism based on orbital motion of protons and deuterons, respectively.

Sublimated hexamethylbenzene crystals over $99.9 \%$ in purity were acquired from Sigma Aldrich. Deuterated hexamethylbenzene crystals over $99.2 \%$ in isotopic ratio were acquired from $\mathrm{CDN}$ Isotopes, Canada. The magnetic susceptibility was measured by an MPMS (magnetic property measurement system) SQUID magnetometer fabricated by Quantum Design, U.S.A. The samples were mounted onto a quartz paddle by GE varnish with $H$ applied along the direction parallel to the molecular planes. For the measurements of when $H$ was applied perpendicular to the molecular planes, two quartz stoppers were employed to secure the sample.

Figure 1(a) shows the warming and cooling curves of the magnetic susceptibility $\chi(T)$ of HMB measured at $H=1 \mathrm{kOe}$ aligned along the direction of the molecular planes. During cooling, a step-up type of discontinuity is evident at $T_{\mathrm{C}}^{\prime}{ }_{\mathrm{H}}=110.8 \mathrm{~K}$ (inset of Fig. 1(a)) signaling the onset of methyl group gearing. The reason why this feature occurs is explained below. During warming, the same transition occurs at $T_{\mathrm{C}_{\mathrm{H}}}=117.8 \mathrm{~K}$. Throughout the existing literature, the critical temperature of this transition has been reported to occur either near $110 \mathrm{~K}[23,24]$ or near $118 \mathrm{~K}[25,26]$. It is now apparent that such discrepancies are not due to sample quality or methodology but due to whether the measurements were carried out during cooling or warming. $T_{\mathrm{C}_{-} \mathrm{H}}$ remained constant of $H$ up to $30 \mathrm{kOe}$. Near $40 \mathrm{~K}$, a small shoulder anomaly is observable to which we attribute to be a critical temperature separating the ground tunneling state from thermally excited tunneling states [21]. Near $20 \mathrm{~K}, \chi(T)$ begins to diverge. Neutron powder diffraction measurements at these temperatures and lower suggested the occurrence of inter-molecular ordering between methyl groups of adjacent molecules [7,27] leading us to conclude that long-range ordering is established below $20 \mathrm{~K}$ where gearing of the methyl groups at the macroscopic level takes place. This is in contrast to gearing occurring only at the molecular level near $T_{\mathrm{C}_{-} \mathrm{H}}$ reminiscent of shortrange correlations, a common manifestation of systems possessing magnetic frustration. The van der Waals interactions in HMB are highly delocalized [3]. Moreover, each rotation of a methyl group involves the exchange of three indistinguishable protons so exchange interactions are bound to happen which should increase with decreasing temperature. This qualitatively explains the divergence of the susceptibility below $20 \mathrm{~K}$. However, a more thorough quantum mechanical treatment is definitely needed.

Figure 1(b) shows the six methyl groups of the HMB molecule with alternating spin directions (arrows) pointing radially inward and outward to represent the rotational motion along the clockwise and anticlockwise directions, respectively. No other directions are allowed since the protons are not capable of orbiting out of their respective planes. This renders the six methyl groups to have $2^{6}$ possible con-
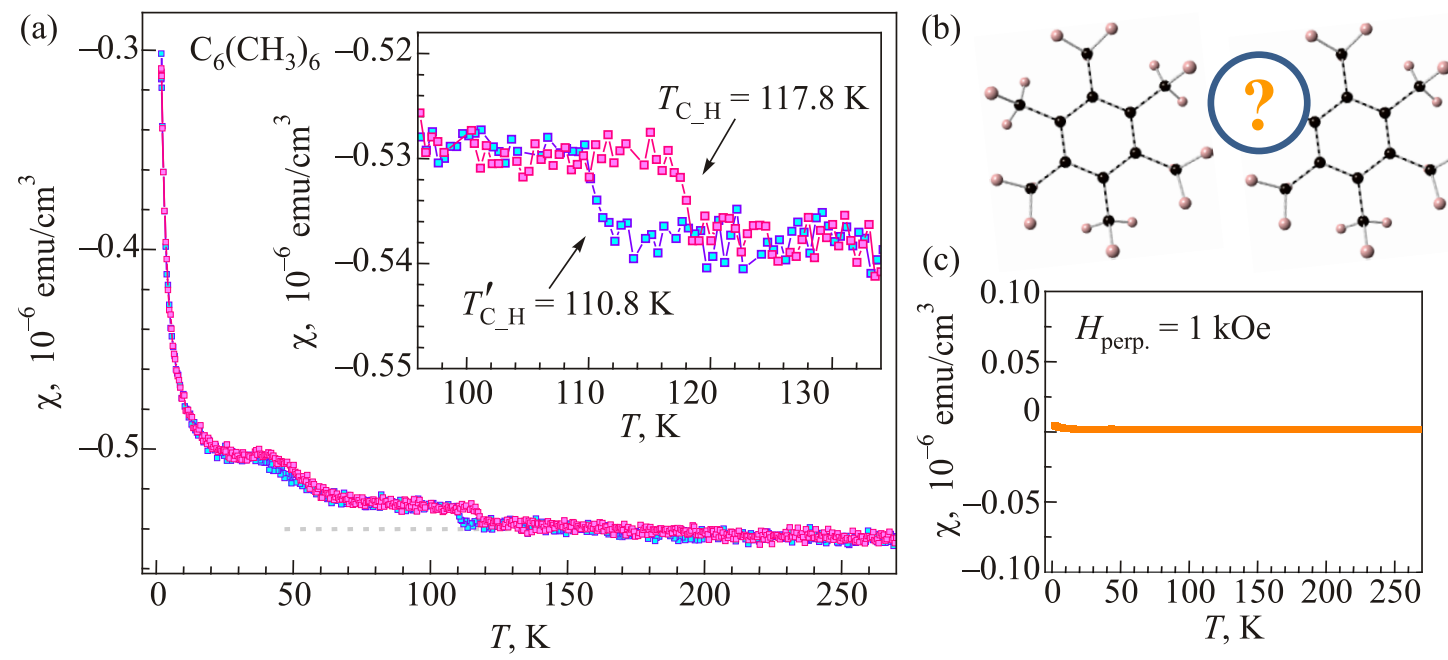

Fig. 1. (a) (Color online) Volume susceptibility $\chi(T)$ of hexamethylbenzene $\mathrm{C}_{6}\left(\mathrm{CH}_{3}\right)_{6}$ with respect to temperature measured in an applied magnetic field of $H=1 \mathrm{kOe}$ along the direction parallel to the molecular planes. Inset is an enlargement of the region showing the transition between the near-cubic and triclinic phases. The grey dashed line represents how $\chi(T)$ should behave if ordering of the methyl groups did not occur. (b) Two adjacent $\mathrm{C}_{6}\left(\mathrm{CH}_{3}\right)_{6}$ molecules in the near-cubic phase along the [1,1,1] direction. Left molecule shows the spin configuration (arrows) of HMB according to the rotational directions of its methyl groups below $T_{\mathrm{C}_{-} \mathrm{H}}$. The question mark represents a conflict of which molecular configuration the adjacent molecule should partake when establishing long-range order toward lower temperatures. (c) $\chi(T)$ for the case when $H=1 \mathrm{kOe}$ was applied along the direction perpendicular to the molecular planes. 
figurations of which the lowest configuration, three inward plus three outward, has a 20-fold degeneracy [28]. According to the Jahn-Teller theorem, a system possessing degenerate energy levels will tend to distort its geometry in order to create a unique state with the lowest energy; otherwise the system would not be stable. Moreover, according to neutron powder diffraction measurements [27] the methyl groups become elongated and more tilted out of plane in the near-cubic state, explicable if they are considered to be consequences of Jahn-Teller distortions. From such, the structural phase transition from triclinic to a near-cubic one at $T_{\mathrm{C} H}^{\prime}$ appears to be magnetically driven [28]. This also helps explain the discontinuity in $\chi(T)$ upon crossing $T_{\mathrm{C}}^{\prime}$ : the net magnetization in each molecule stemming from the methyl groups should be zero if the molecule is hexagonally symmetric such as in the triclinic phase (provided there is an equal distribution of spins pointing in and pointing out), however, a net magnetization arises in the near-cubic phase due to breaking of symmetry of the methyl groups rendering the magnetic moments to cant.

Geometric frustration at the inter-molecular level also exists. Consider the spin direction of the nearest methyl group of an adjacent molecule marked by a "?" symbol in Fig. 1(b). It is clear that a conflict exists in which direction the spin should orient. The current spin configuration is unique to all current known systems that possess geometric frustration; notable ones include Kagome staircases [29,30] and triangular lattices [31-34].

Figure 1(c) shows $\chi(T)$ for the case when $H=1 \mathrm{kOe}$ was oriented along the direction perpendicular to the molecular planes. $\chi(T)$ remained nearly temperature-independent with no distinctive features near $T_{\mathrm{C}_{-} \mathrm{H}}, 40$ or $20 \mathrm{~K}$ which is in agreement with the notion that the direction of the magnetic moments of the methyl groups lie mainly within the molecular planes. This result also helps discount the probability that the features observed in Fig. 1(a) are due to impurities. A slight uptick below $15 \mathrm{~K}$ may be attributed to the shrinking of the quartz tube which dislocated the sample from the detection coil. The option to auto-center the sample after each measurement was disabled since the voltage signal of the SQUID for these experiments was rather weak. We note that the magnitude of $\chi(T)$ along the direction normal to the molecular planes was less negative than the in-plane direction which was rather surprising. Different magnetometers and sample rods were employed to check this discrepancy, even in one case, three samples were stacked together so a larger signal can be obtained. However, all measurements yielded similar results.

Figure 2 shows $\chi(T)$ for HMB- $d_{18}$ at $5 \mathrm{kOe}$. The step anomalies related to the gearing of methyl groups in HMB- $d_{18}$ occur $14-15 \mathrm{~K}$ higher at $T_{\mathrm{C} \_\mathrm{D}}^{\prime}=126.7 \mathrm{~K}$ and $T_{\mathrm{C}_{-} \mathrm{D}}=132.2 \mathrm{~K} . T_{\mathrm{C} \_\mathrm{D}}$ is in excellent agreement with Raman spectroscopy [35], specific heat [36] and inelastic neutron scattering measurements [7]. The anomaly near $40 \mathrm{~K}$ in HMB becomes a peak and is shifted to $42 \mathrm{~K}$ in HMB- $d_{18}$.

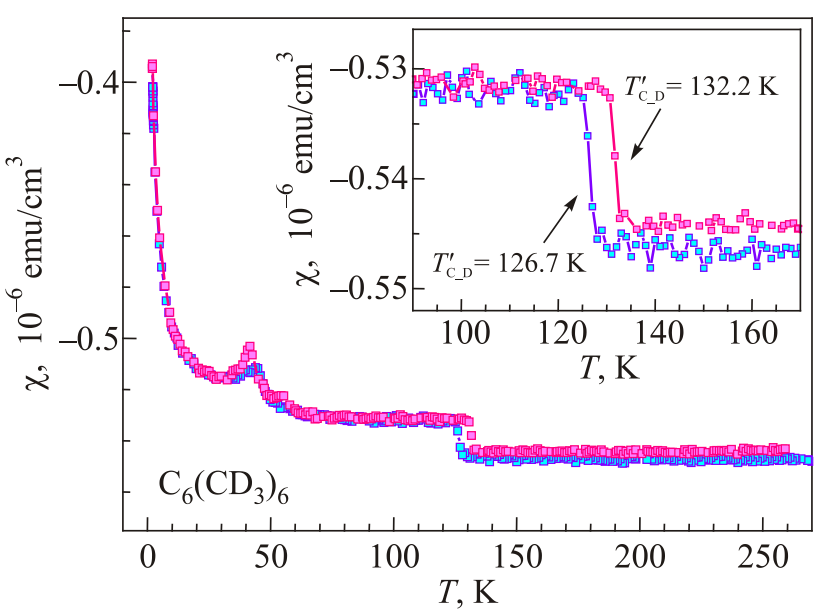

Fig. 2. (Color online) $\chi(T)$ of deuterated hexamethylbenzene $\mathrm{C}_{6}\left(\mathrm{CD}_{3}\right)_{6}$ under $H=5 \mathrm{kOe}$. Inset is an enlarged view of the structural transitions between the near-cubic and triclinic phases.

The diverging of $\chi(T)$ in HMB- $d_{18}$ also occurs near $20 \mathrm{~K}$, however, it is slightly less pronounced than HMB. The electronic configuration of HMB and HMB- $d_{18}$ may be treated as being nearly identical so the observation of isotope effects is unequivocal evidence that the involved magnetic behavior is based on the correlated orbital motion of protons and deuterons, respectively.

In conclusion, the ordering of the orbital motion of protons within hexamethylbenzene starting from below $117.8 \mathrm{~K}$ is found to stem from magnetic interactions between neighboring methyl groups. The symmetry and rotational motion of the methyl groups at the molecular level induces a 20-fold energy degeneracy which is removed via Jahn-Teller distortions resulting in the triclinic phase transitioning into a near-cubic structure phase with a unique set of lattice distortions. Similar behavior was observed in deuterated hexamethylbenzene, however, the onset temperature shifted to $132.2 \mathrm{~K}$. Below $20 \mathrm{~K}$, the divergent behavior of the magnetic susceptibility indicates that the methyl groups establish long-range order. A magnetic system based on a species other than electron spin or nuclear magnetic moments will provide physicists another framework to verify existing quantum and effective field theories and possibly uncover new phenomena. Magnetic behavior is expected to also occur in other poly-methylbenzenes as well as compounds possessing $\mathrm{CH}_{4}, \mathrm{NH}_{3}$ and $\mathrm{NH}_{4}^{+}$groups which are well-known to also exhibit rotational tunneling.

\section{Acknowledgments}

The author wishes to thank the National Natural Science Foundation of China for their support via grants numbers 11374307 and 11650110430 .

1. K. Lonsdale, Proc. R. Soc. London Ser. B 123, 494 (1929).

2. L.O. Brockway and J.M. Robertson, J. Chem. Soc. 1324 (1939). 
3. J. Hoja, A.M. Reilly, and A. Tkatchenko, WIREs Comput. Mol. Sci. 7, e1294 (2017).

4. L. Pauling, Phys. Rev. 36, 430 (1930).

5. G.L. Hoatson, R.L. Vold, and T.Y. Tse, J. Chem. Phys. 100, 4756 (1994).

6. E.R. Andrew, J. Chem. Phys. 18, 607 (1950).

7. J.A. Stride, J.M. Adams, and M.R. Johnson, Chem. Phys. 317, 143 (2005).

8. K.M. Gough, B.R. Henry, and T.A. Wildman, J. Mol. Struct. Theochem. 124, 71 (1985).

9. L.D. Iroff, J. Comput. Chem. 1, 76 (1980).

10. V. Melissas, K. Faegri, Jr., and J. Almlöf, J. Am. Chem. Soc. 107, 4640 (1985)

11. W.R. Woolfenden and D.M. Grant, J. Am. Chem. Soc. 88, 1496 (1966).

12. J. Jonas, J. Chem. Phys. 47, 4884 (1967).

13. E.E. Burnell, C.A. de Lange, and W.L. Meerts, J. Chem. Phys. 145, 091101 (2016).

14. Z.M. El Saffar, J. Chem. Phys. 36, 1093 (1961).

15. S. Takeda, G. Soda, and H. Chihara, Solid State Commun. 36, 445 (1980).

16. K. Börner, G. Diezemann, E. Rössler, and H.M. Vieth, Chem. Phys. Lett. 181, 563 (1991).

17. P.S. Allen and A. Cowking, J. Chem. Phys. 47, 4286 (1967).

18. J.A. Adams, A.S. Ivanov, M.R. Johnson, and J.A. Stride, Physica B 350, e351 (2004).

19. E.P. Jones and M. Bloom, Phys. Rev. Lett. 28, 1239 (1972).

20. C. Kittel, Introduction to Solid State Physics, 6th ed., John Wiley \& Sons (1986), p. 299.

21. F. Yen, Z.Z. Zhao, S.X. Hu, and L. Chen, Angew. Chem., Int. Ed. 56, 13675 (2017).

22. F. Yen, J. Phys. Chem. C 122, 16304 (2018).

23. H.M. Huffman, G.S. Parks, and A.C. Daniels, J. Am. Chem. Soc. 5, 1547 (1930).

24. O. Schnepp, J. Chem. Phys. 29, 56 (1958).

25. M. Frankosky and J.G. Aston, J. Phys. Chem. 69, 3126 (1965).

26. T. Atake, H. Gyoten, and H. Chihara, J. Chem. Phys. 76, 5535 (1982).

27. J.A. Stride, Acta Crystallogr., Sect. B: Struct. Sci. 61, 200 (2005)

28. F. Yen, J. Phys. Chem. C 122, 29628 (2018).

29. F. Yen, R.P. Chaudhury, E. Galstyan, B. Lorenz, Y.Q. Wang, Y.Y. Sun, and C.W. Chu, Physica B 403, 1487 (2008).

30. L.I. Vergara, J. Cao, L.-C. Tung, N. Rogado, F. Yen, Y.Q. Wang, R.J. Cava, B. Lorenz, Y.-J. Wang, and J.L. Musfeldt, Phys. Rev. B 81, 012403 (2010).

31. F. Yen, C.R. dela Cruz, B. Lorenz, E. Galstyan, Y.Y. Sun, C.W. Chu, and M.M. Gospodinov, J. Mater. Res. 22, 2163 (2007).

32. F. Yen, C.R. dela Cruz, B. Lorenz, Y.Y. Sun, Y.Q. Wang, M.M. Gospodinov, and C.W. Chu, Phys. Rev. B 71, 180407(R) (2005).

33. B. Lorenz, F. Yen, M.M. Gospodinov, and C.W. Chu, Phys. Rev. B 71, 014438 (2005).
34. C. dela Cruz, F. Yen, B. Lorenz, Y.Q. Wang, Y.Y. Sun, M.M. Gospodinov, and C.W. Chu, Phys. Rev. B 74, 060407(R) (2007).

35. P.N. Prasad, S.D. Woodruff, and R. Kopelman, Chem. Phys. 1, 173 (1973).

36. T. Fujiwara, A. Inaba, T. Atake, and H.J. Chihara, Chem. Thermodyn. 24, 863 (1992).

\section{Магнітні властивості гексаметилбензолу}

Fei Yen

Представлено вимірювання магнітної сприйнятливості $\chi(T)$ гексаметилбензолу $\mathrm{C}_{6}\left(\mathrm{CH}_{3}\right)_{6}(\mathrm{HMB})$, а також його дейтерованого аналога $\mathrm{C}_{6}\left(\mathrm{CD}_{3}\right)_{6}\left(\mathrm{HMB}-d_{18}\right)$ в діапазоні 2-300 K. При прикладенні зовнішнього магнітного поля вздовж напрямку молекулярних площин та охолодженні виявлено сплеск в $\chi(T)$, що зумовлено виникненням внутрішньомолекулярної взаємодії груп $\mathrm{CH}_{3}$ при $T_{\mathrm{C} \_\mathrm{H}}^{\prime}=110,8 \mathrm{~K}$ для НМВ та груп $\mathrm{CD}_{3}$ при $T_{\mathrm{C} \_\mathrm{D}}^{\prime}=126,7$ К для $\mathrm{H}_{\mathrm{MB}} d_{18}$. При нагріванні такі ж особливості спостерігалися поблизу $T_{\mathrm{C}_{-} \mathrm{H}}=117,8 \mathrm{~K}$ та $T_{\mathrm{C} \_\mathrm{D}}=132,2 \mathrm{~K}$. Пікова аномалія поблизу $40 \mathrm{~K}$ імовірно обумовлена досягненням системою основного тунельного стану. Близько 20 К розбіжність $\chi(T)$ може підтверджувати встановлення далекого порядку унаслідок міжмолекулярної обертальної взаємодії метильних груп. У разі прикладення зовнішнього магнітного поля перпендикулярно до молекулярних площин $\chi(T)$ не залежить від температури. Наші результати демонструють, як корельований періодичний рух протонів, притаманний багатьом молекулярним твердим тілам, впливає на поведінку їх магнітних властивостей, що досі не враховувалося.

Ключові слова: магнітна сприйнятливість, молекулярна взаємодія, фазовий перехід, метильні групи.

\section{Магнитные свойства гексаметилбензола}

\section{Fei Yen}

Представлены измерения магнитной восприимчивости $\chi(T)$ гексаметилбензола $\mathrm{C}_{6}\left(\mathrm{CH}_{3}\right)_{6}(\mathrm{HMB})$, а также его дейтерированного аналога $\mathrm{C}_{6}\left(\mathrm{CD}_{3}\right)_{6}\left(\mathrm{HMB}-d_{18}\right)$ в диапазоне $2-300 \mathrm{~K}$. При приложении внешнего магнитного поля вдоль направления молекулярных плоскостей и охлаждении обнаружен всплеск в $\chi(T)$, обусловленный возникновением внутримолекулярного взаимодействия групп $\mathrm{CH}_{3}$ при $T_{\mathrm{C}}^{\prime} \mathrm{H}=110,8 \mathrm{~K}$ для $\mathrm{HMB}$ и групп $\mathrm{CD}_{3}$ при $T_{\mathrm{C}}^{\prime} \mathrm{D}=126,7 \mathrm{~K}$ для $\mathrm{HMB}-d_{18}$. При нагревании такие же особенности наблюдались вблизи $T_{\mathrm{C}_{-} \mathrm{H}}=117,8$ К и $T_{\mathrm{C}_{-} \mathrm{D}}=132,2 \mathrm{~K}$. Пиковая аномалия вблизи 40 К предположительно обусловлена достижением системой основного туннельного состояния. Около $20 \mathrm{~K}$ расхождение $\chi(T)$ может подтверждать установление дальнего порядка 
вследствие межмолекулярного вращательного взаимодействия метильных групп. В случае приложения внешнего магнитного поля перпендикулярно молекулярным плоскостям $\chi(T)$ не зависит от температуры. Наши результаты демонстрируют, как коррелированное периодическое движение протонов, присущее многим молекулярным твердым телам, влияет на поведение их магнитных свойств, что до сих пор не учитывалось.

Ключевые слова: магнитная восприимчивость, молекулярное взаимодействие, фазовый переход, метильные группы. 